Reunifying versus Living Apart Together Across Borders: A Comparative Analysis of Sub-Saharan Migration to Europe

\begin{tabular}{|r|l|}
\hline Journal: & International Migration Review \\
\hline Manuscript ID: & IMRE-2013-04-0124.R1 \\
\hline Keywords: & Family reunification, Africa, Europe \\
\hline Abstract: & $\begin{array}{l}\text { This article studies the process of reunification in Europe among "living } \\
\text { apart together across borders" (LATAB) couples of African origin (DR } \\
\text { Congo, Ghana and Senegal). Couple reunion is conceived as a multi-level } \\
\text { process, wherein state selection (through immigration policies in } \\
\text { destination countries) interacts with self-selection (at the couple level), } \\
\text { under influence of the social context at origin. Based on event-history } \\
\text { analyses of the MAFE project, empirical results show that LATAB is a } \\
\text { majority and durable living arrangement for Sub-Saharan migrants, that } \\
\text { the odds if reunifying depend on gender and inter-generational } \\
\text { relationships, and that restrictive contexts at destination do not deter } \\
\text { couple reunion. }\end{array}$ \\
\hline
\end{tabular}




\section{Reunifying versus Living Apart Together Across Borders: \\ A Comparative Analysis of Sub-Saharan Migration to Europe}

\section{Introduction}

Over the last two decades, European rules regarding family reunification have become increasingly restrictive. In the 1990s especially, most countries adopted new laws to curb the number of new migrants entering on family grounds and also to select applicants for family reunification more explicitly (Kraler, Kofman et al. 2011). This trend towards restrictiveness is anchored in the common wisdom that family reunion is the universal goal of all migrants: there would be no selection in the reunification process at the level of the migrants and their relatives; and the states would thus be the only players to determine whether reunion should occur or not. This perception is the result of a double bias. The first bias is of ideological nature. The view that all couples are expected to reunify is based on a western-centric view of the family, in which a "normal" couple is made of two cohabitating partners. This ideal type, already contradicted in Western countries by the existence of "living apart together" (LAT) couples, does neither fit the family norms that apply in migrants origin countries. The second bias is of methodological nature. Many data sources (especially the administrative ones) suffer from their "methodological nationalism" (Bauböck and Faist 2010). They detail the number of reunified families in destination countries and they compare these families with non-migrant families, but lacking information on the relatives who stayed at origin (the socalled "left behinds"), they fail to measure the extent of reunification compared with families who remain separate. They are also ill-suited for studies on the factors of reunification because they cannot be used to compare those who reunified with those who did not. 
This article aims at overcoming this doubly biased view of family reunion. We extend the western notion of "living apart together" (LAT) couples to partners who live separately because of international migration, by referring to "living apart together across borders" (LATAB) couples, hence suggesting that these "transnational couples" (wherein partners live in separate countries) may select themselves (or not) into this way of life, as do LAT couples within the borders of the countries where they reside. The objective of this paper is to study how LATAB couples of African origin turn (or not) into reunified couples in Europe. More specifically, we test the hypothesis that reunification is a multi-level process, wherein state selection (through immigration policies in destination countries) interacts with self-selection. In our framework, "self" refers to LATAB couples that are conceived neither as unitary nor as isolated decision units. First, we acknowledge that there might be divergences between partners within LATAB couples regarding the aspiration and decision to reunify or not. Second, couples are conceived as being under the influence of their origin context, especially regarding gender and family norms.

To study the process of couple reunification (timing and factors), we use the data of the MAFE project ${ }^{1}$ that collected life histories in three African (DR-Congo, Ghana, Senegal) and

\footnotetext{
${ }^{1}$ The MAFE project is coordinated by INED (C. Beauchemin) and its other participants are the Université catholique de Louvain (B. Schoumaker), Maastricht University (V. Mazzucato), the Université Cheikh Anta Diop (P. Sakho), the Université de Kinshasa (J. Mangalu), the University of Ghana (P. Quartey), the Universitat Pompeu Fabra (P. Baizan), the Consejo Superior de Investigaciones Científicas (A. González-Ferrer), the Forum Internazionale ed Europeo di Ricerche sull'Immigrazione (E. Castagnone), and the University of Sussex (R. Black). The MAFE project received funding from the European Community's Seventh Framework Programme under grant agreement 217206. The MAFE-Senegal survey was conducted with the financial support of INED, the Agence Nationale de la Recherche (France), the Région Ile de France and the FSP programme 'International
} 
six European (Belgium, France, Italy, Spain, The Netherlands, UK) countries, among migrants, returnees and non-migrants. Of great interest for this paper is the possibility, with the MAFE data, to compare reunified couples with LATAB couples, taking into account their changing situation over time. Using techniques of event-history analysis, we measure the propensity to reunify and analyze, through discrete-time logit models, the factors associated with partners' reunification in Europe. After this introduction, the next section provides a framework for the study of couple reunification. The following part sets out the data and methods. Results are then presented and their significance and limitations discussed in the conclusive section.

\section{A Framework for the Study of Couples' Reunification}

\section{Transnational couples: from qualitative evidence to quantitative measures}

Since the 1990s, a large number of socio-anthropological studies have shown that migrant families tend to adopt ways of life that transcend borders, as exemplified by the multiplication of journal special issues and edited books on "transnational families" (Bryceson, Vuorela et al. 2002; Le Gall 2005; Mazzucato and Schans 2011; Razy and Baby-Collin 2011; Carling, Menjivar et al. 2012). "Transnational family" has become the usual term to label this form of family arrangement, where partners, parents and children live in separate countries, yet maintaining relationships that allow them to "do family" at a distance. Even though these types of family arrangements are certainly not completely new, they are facilitated nowadays

Migrations, territorial reorganizations and development of the countries of the South'. For more details, see: http://mafeproject.site.ined.fr/en/ 
by the increasingly easiness to travel and to communicate at long distance (see Mazzucato et al. in this issue for a more complete literature review on transnational families).

Although the flourishing of case studies in various parts of the world suggests that transnational families are not a marginal phenomenon, measures of non-reunification remain quite rare for methodological reasons. Such measures indeed require to count both those who reunify and those who do not, who -by definition- live in different countries, while most data are collected independently in single countries and do not provide information about family members living abroad. Some scattered studies nevertheless show that non-reunification may be a significant phenomenon. In the context of Mexican migration to the US, for instance, Kanaiaupuni (2000, p.1337) shows that "migration more often means separation than reunification among married couples". In a totally different setting, and already using the MAFE data, Baizan et al. (2013) have shown that living apart together across borders is a quite common and long-lasting situation among Senegalese couples in Europe: 10 years after separation due to migration, only one couple out of five was reunified in Europe (France, Italy or Spain). Reunification at origin, i.e. in Senegal after the return of the male migrant who used to live in Europe, appeared as a more common situation that characterized about one couple out of four. How to explain that partners remain separated across borders, even where they are allowed to reunify? 


\section{Rationale for Living Apart Together Within and Across Borders}

Economic theories provide a first strand of explanations ${ }^{2}$. Even though it was not focused on family migration, the neo-classical theories of migration helps to understand that living apart together may be a rationale choice for migrants and their families. Seen as income maximizers, migrants would have interest in reunification only in the cases where the spouse migration would allow both to maximize gains and to minimize costs of living for the family. In contexts where there are deep gaps in earnings and costs of living between origin and destination places, reunification may not be the preferred option, even though -following the human capital theory of migration- this may depend on the employment prospects at destination of the left behind. The New Economics of Labor Migration (NELM) offer other avenues to explain that some couples may prefer to live apart together, within or across borders. First, migration is seen in this set of theories as a household strategy to diversify income sources and risks. By bringing family members to the same place, reunification would counter this logic. Second, migrants are seen as target earners who move to overcome various constraints in their place of origin (for instance, the lack of access to credit) with the aim of returning once they have achieved what they could not achieve without migration. Following this rationale, reunification at destination would be a way to delay the time of achievement and return.

The theoretical notion that families have strategies of diversification by spreading their members in various places echoes demographic research that has shown the extent of "living

\footnotetext{
${ }^{2}$ For a more developped review of economic theories regarding family (non-)reunification, see Gonzalez-Ferrer (2012).
} 
apart together" couples -albeit they were not labelled as such-in some Sub-Saharan regions (Findley 1997; Pilon and Vignikin 2006). According to the MAFE household surveys (Table 1), in the late 2000's, the proportion of people who are in partnership (marriage or consensual union) but who do not live with (any of) their partner ranges from $10 \%$ in Kinshasa (DRCongo) to $22 \%$ in Dakar (Senegal) and $41 \%$ in Accra and Kumasi (Ghana) ${ }^{3}$. This is not a new phenomenon (Findley 1997; Coe 2011). It rather reflects persisting family norms in which the process of couple formation implies low levels of interaction within couples for a number of reasons: spouses often do not choose each other; they have a large age gap; and in some countries, polygamy also adds distance between partners. LAT within borders is especially frequent in contexts where the model of the extended family prevails, i.e. where the elders exert a strong power over the younger and where lineage solidarity is expected to be higher than partners' solidarity within the couple.

(Table 1 about here)

\section{Social Forces against Reunification}

The social rationale for LAT within borders also applies for LAT across borders. Social norms, rules and values in origin countries -in other terms the "institutional context" of migration- are of tremendous significance to understand why family reunification is not a systematic option for migrants. Even though some migrants may act by themselves, the general idea that migration is simply the result of an individual decision has been ruled out for long. Similarly, couple reunification is not only determined by the partners: it can be strongly influenced by their social and family context. Where migration is conceived as an implicit

\footnotetext{
${ }^{3}$ Note that very similar results are obtained with DHS surveys.
} 
contract between the migrant and his/her family or community of origin, the members of the extended family -and especially the elders- have a direct interest in maintaining the migrants' close relatives (spouses and children) at origin. First, they constitute a labor force, which is all the more important when outmigration is significant (Guilmoto 1998). Second, they constitute a form of insurance that the migrant will continue to send remittances (Mazzucato 2009). The elders' opposition towards reunification is explicitly mentioned in several studies on Senegalese migration, where moving abroad is largely a matter of the extended family (and not only the result of an individual or couple decision) and where the left-behind spouses commonly reside with their in-laws (Barou 1993; Guilmoto 1998), as it is also observed in Ghana (Coe 2011).

In addition of inter-generational relationships, gender norms also play an important role in couple non-reunification. In some societies, migration is still considered as a male matter and females are not expected to migrate, even under control of their husband. Even in settings as varied as Mexico or Morocco, migration is still perceived as a threat to social reproduction because it represents a possible mean for women to raise their power and gain some autonomy through their exposure to more egalitarian norms (Hondagneu-Sotelo 1992; De Haas and Fokkema 2010). Barou (1993) reported that some Senegalese male migrants in France opposed reunification because of their fear of divorce in a legal context that is more favorable to women than in their home country. Similar observations apply to reunification with children: it has been reported that bringing children in Europe is a source of stigmatization in Morocco, Tunisia and Senegal because it exposes them to external norms that contradict the cultural and religious values at origin, as well as traditional authorities (Barou 1993; Riccio 2008; De Haas and Fokkema 2010; Mazzella and Boubakri 2011). But this does not apply equally to all origin countries in Africa: comparing migrants from Senegal and Ghana in Italy, Riccio (2008) did not observe such reluctance among the later who origin from a more 
egalitarian society. In any case, when it exists, the preference for rearing children in the home country is a strong deterrent for mothers' reunification: they have to stay behind to take care of the children.

Societies are obviously diverse within countries and depicting attitudes towards reunification as if there was no internal diversity is obviously an oversimplication. Previous studies have for instance shown that reunion with children and spouses is less likely among Senegalese migrants from more patriarchal ethnic groups (González-Ferrer, Baizán et al. 2012; Baizán, Beauchemin et al. 2014). Similarly, attitudes towards reunification vary according to the socio-cultural background of migrants families.

\section{Women Left Behind: Ambivalant Aspirations and Bargaining Power}

The literature suggests that left behind wives have ambivalent intentions regarding migration and reunification. On the one hand, gender inequalities in home countries may act as push factors and encourage migration, as a way to gain more autonomy. And it might be especially true in regions where the wives are left with their in-laws which tend to increase social control over them (Mondain 2009; Coe 2011). On the other hand, various studies also report that leftbehind women gain some autonomy, esteem and role expansion thanks to the absence of their husband, even in patriarchal settings such as Mexico: they engage in new economic activities, perform multiple roles, gain new skills, such as budgeting, etc. (Hondagneu-Sotelo 1992). In a Nigerian survey, the greater autonomy of women, thanks to their husband departure, was explicitly cited as a reason for non-migration by a majority of women (Findley 1997). In Senegal, as well, especially in Dakar, the additional work load due to the absence of the husband is said to be compensated by gains in autonomy (Tall and Tandian 2010). In these cases where being left behind is associated to a greater independence, reunification is not necessarily an aspiration. 
The literature also suggests a relationship between left behinds' attitudes towards reunification and human capital: in many contexts, the more educated ones are found to be more likely to reunify (Kanaiaupuni 2000; González-Ferrer 2007; Toma and Vause 2013). Educated women would have both a higher interest in family reunification and a greater agency to realize their migratory project. On the one hand, especially in patriarchal contexts, they are the more likely to suffer from discrimination on the labor market, which may enhance their aspiration for international mobility (Kanaiaupuni 2000; Toma and Vause 2013). On the other hand, the more educated wives are also certainly those with the higher bargaining power to convince their husband and/or subvert patriarchal authority in order to negotiate the realization of their migratory project. Even though they often end up being under-employed at destination (Kofman 2000), educated women are those who have the best employment prospects (and thus the highest chances to increase the couples incomes) which may help them in negotiating their departure, in a context where the capacity to start a procedure of reunification is in the hands of the partner at destination. Finally, educated women are those who have the greater benefit in terms of gender relationships: Mexican educated women in the US have consistently higher levels of control in relationships with males than their less-educated counterparts, who even have lower level of control than nonmigrant women in the origin country (Parrado and Flippen 2005).

\section{Migrants' Agency and Policy Constraint}

Governments in receiving countries play obviously a major role in the reunification process: they are those who set the rules that migrants and their partners must comply with if they wish to reunify legally. States define who is eligible, taking into account the characteristics of both the sponsor (the migrant who asks for reunification) and -especially since the $2000 \mathrm{~s}-$ of his/her relatives. Reunification thus depends on a state selection, in addition of a self-selection 
at the couple level (which may itself depend on a partners' bargain under social pressure). Even though, the European Union established in 2003 the right for family reunion in all its member states, specific rules regarding reunification remain very diverse across the region.

The Migration Integration Policy Index (MIPEX) provides a good overview of this diversity. Among other migration policy domains, it analyses how restrictive are the countries regarding family reunification, taking into account four dimensions: eligibility (who can apply for reunification), conditions for reunification (what are the criteria), security of status (how discretionary is the procedure), and rights associated to reunification (how similar are the rights of the sponsors and reunified relatives compared to Europeans). These four dimensions are averaged together in a global score that classifies countries from critically unfavorable $($ score $=0)$ to favorable countries (score $=80$ to 100 ). Table 2 shows the MIPEX score (2007) of the European countries of interest in this study. They fall into two categories: slightly (score $=60$ to 79 , such as Belgium, Spain and Italy) and halfway favorable (score $=41$ to 59 , such as France, the Netherlands, the United Kingdom). In other terms, the right for family reunification is globally respected in these countries, but some of them are more restrictive and, sometimes, beyond the requirements of the European Directive on family reunion (Pascouau and Labeyle 2011). The Netherlands, Spain and Belgium allow non-married partners to reunify (provided that they can duly attest a stable long-term relationship), while France presents the third most restrictive conditions and family definitions. According to MIPEX, Italy, France and the Netherlands impose disproportionate housing, and/or income requirements and fees, the latter two also use excessively discretionary and bureaucratic procedures (Huddleston 2011). Regulations regarding reunification are changing over time, sometimes at a frantic pace, such as in France, where rules became tougher since the mid 1980's. On the contrary, rules grew in openness in Spain and followed an erratic path in Italy (Mezger and Gonzalez-Ferrer 2013). Unfortunately, except from the ImPol database that only 
covers Spain, Italy and France, there is currently no available database to compare systematically across countries how policies evolved in the last decades ${ }^{4}$. However, the general trend is rather for governments to adopt more restrictive policies, some of them (such as the Netherlands) even lobbying to tighten up on European norms (Kraler 2010; Huddleston 2011).

(Table 2 about here)

Even though they have the power to set the legal framework for family reunification, governments are not the only players in the process of family reunion. First, as already shown by Bledsoe and Sow (2008), migrants have some agency and adapt their demographic behaviors (e.g. marriage or childbearing) to comply with the legal rules that allow for regular family reunification. Second, migrants may also opt for "de facto reunification" (Gonzalez Ferrer 2011), i.e. to regroup their partner without using the legal channel of family reunification. De facto reunification can be regular when partners enter through alternative legal channels (as refugees, students or workers). It was, for instance, the case before Northern European countries decided to stop labor migration and adopted restricted immigration policies in the mid-1970s: family reunification -that existed in fact- was virtually non-existent in administrative statistics. De facto reunification can also be irregular, as observed in Spain (Gonzalez Ferrer 2011) where there is a relative "tolerance" towards irregular residence migration (undocumented migrants have access to some social services, and are rarely subject to identity checks once inside the country...). Lututala (2009) also

\footnotetext{
${ }^{4}$ The MIPEX is updated since 2007 but it does not cover the previous years that are precisely of interest in this paper.
} 
suggests with anecdotal evidence that the complexity and length of the legal procedures for family reunification pushes some Congolese migrants to reunify irregularly in Europe.

\section{Hypotheses}

Several important ideas emerge from this literature review. The first contradicts the western public common wisdom that reunification is widespread if not systematic among migrants: even though measures are still quite rare, it appears that living apart together across borders may be a rational, common and long-lasting arrangement. To explain that reunion at destination is not a universal option for couples who happen to be separated because of international migration, we assume that reunification is a multi-level selection process that combines state-selection (through immigration policies in receiving countries) and selfselection. Destination countries are not the only players to decide who reunifies or not, simply because couples have firstly to decide whether they opt or not for reunification. It remains that reunification may be an object of negotiation within couples, wherein partners may have diverging aspirations. And this bargain may be strongly influenced by the social context at origin, and especially the norms regarding gender relationships. This framework is detailed in a set of three hypotheses.

Hypothesis 1. We expect living apart together across borders to be a frequent arrangement among African couples, with a propensity to reunify that varies according to the origin country: more gender egalitarian societies are assumed to be generally more favorable to reunion in Europe. More specifically, in line with previous research (Riccio 2008; Toma and Vause 2013), we expect that couples from Congo and Ghana will reunify more frequently than those from Senegal, given that all indicators point to much better positions of females in the Congolese and -even more- Ghanaian societies (Table 1). There, and especially in cities, consensual unions and divorces are more frequent among women, polygamy much rarer, and 
women are more engaged in the labor market and more numerous to be engaged in tertiary education. However, other contextual factors could influence the propensity to reunify. In Ghana, the very high level of living apart together couples within the country (Table 1) could translate into high levels of living apart together couples across borders; and the reversal reasoning applies to DR-Congo where LAT is especially low within the country. Furthermore, the deep political turmoil and the economic bankrupt experienced by the Congolese population since the 1990s may be a fostering factor of reunification, as suggested in Belgium -the historical destination- both by the fall in rates of return and the feminization of the Congolese migrant population (Schoonvaere 2010). In short, we expect maximum levels of couple reunification among Congolese migrants and minimum levels among the Senegalese ones.

Hypothesis 2. In addition of its impact on the frequency of reunification, we assume that the context at origin influences the selection process into reunification by couples. In line with the literature, we hypothesize that selection according to human capital will be higher in patriarchal contexts, where social and economic frustrations may be higher for educated women, as are higher the gains they can expect from migration. Reversely, in more egalitarian countries, we expect educational selection to be of lesser significance. However, again, some other contextual factors may blur the results interpretation. The Congolese crisis for instance may well also act as a factor equalizing the risks of reunification, as it is already known that Congolese migration became less selective during and after the civil war. To summarize, we expect reunification to be highly selective according to females' education among Senegalese couples, and non or weakly selective among other couples, especially the Congolese ones.

Hypothesis 3. A basic policy expectation is that more restrictive measures lead to less migration. This assumption can be detailed in two sub-hypotheses, one referring to the couple characteristics, the other to the destination countries. The first is that couples who do not 
comply with the official selection criteria for reunification will have lower probabilities to reunite. More specifically, we expect lesser odds of reunification among couples where the sponsor is undocumented, where the partners are not married, or among couples who do not meet the legal housing and/or income requirements. The second hypothesis would be that host countries with more restrictive policies (such as France, the Netherlands or the UK) tend to discourage reunion when compared to more permissive countries (such as Belgium, Italy or Spain). However, numerous studies have already shown that restrictive migration policies have often no effect and even sometimes effects in contradiction with policy expectations (for a review, see for instance Czaika and De Haas, 2013). Having in mind that migrants and their families can adapt to circumvent restrictions in legal reunification and engage in de facto reunification, we finally assume that the difference between countries according to their level of restrictiveness in matter of reunification may be non-significant.

\section{Methodology}

\section{Conceptual options and methodological implications}

Family reunification is usually defined as the legal procedure through which migrants bring close relatives (i.e. spouse and children, and more rarely other relatives) into their immigration country. In this paper, we conceptualize reunification as a broader phenomenon that includes legal family reunification (i.e. reunification as a legal path of entry) and de facto (regular or irregular) reunification. Focusing on overall reunification, rather than narrowly on legal reunification, is a requirement to test the idea that selection into reunification is not only a state matter but also the product of the couples' agency. Obviously, this conception of reunification forbids using administrative data; it rather takes a source with information on the location of the migrants and their partners, whatever their path of entry into Europe. 
Reunification is furthermore conceived as a process since, by definition, there is a time lapse between the moment of geographical separation and the time of reunion, lapse during which multiple factors can evolve to encourage or deter reunification. Studying reunification thus requires to follow $\mathrm{LATAB}$ couples over time in order to be able to analyze the timing and the factors affecting their probability to regroup. It thus necessitates longitudinal data and analyses. In addition, reunification is conceived as a transnational process since, by definition, the partners are located in separate countries as long as they do not reunify. Studying reunification thus necessitates to disposing of a multi-sited information on the partners and their respective environments. Finally, since our aim is to analyze how the origin and destination contexts shape reunification, we need a set of comparable data allowing to perform a double comparison, both between sending and receiving countries.

\section{Data source: the MAFE Project}

Even though the MAFE project was not specifically designed for the study of the determinants of family reunification, it offers a unique opportunity to analyze how LATAB partners of African origin turn into reunified couples in Europe. Thanks to their transnational, comparative and longitudinal features, the MAFE data ${ }^{5}$ fulfill the above mentioned requirements (Beauchemin 2012). The analyses carried out in this paper rely on sub-samples of individuals who were engaged in a transnational couple (being married or not) for a period of at least one year at some point in time (i.e. at the time of the survey and/or in the past). Furthermore, the subsamples are restricted to interviewees who were left-behind women in

\footnotetext{
${ }^{5}$ For a broader presentation of the MAFE project, see the introductory paper of this volume or, for more details Beauchemin (2012).
} 
Africa and male migrants in Europe ${ }^{6}$. Finally, we use three sub-samples of 153 Congolese, 280 Ghanaian and 543 Senegalese couples, for which the data were obtained either from males interviewed in Europe or females surveyed in Africa, a combination made possible because the questionnaire contains information not only on the interviewee but also on his/her present and past partner(s) ${ }^{7}$.

To take into account the changing characteristics of the couples (and of the partners themselves), the data was arranged as a couple-year dataset ${ }^{8}$ in which each couple appears when it enters in a LATAB situation for the first time (i.e. when the male migrates out of Senegal, Ghana or Congo, leaving behind his wife, or when the partners start their relationship while living in separate countries) and disappears when the LATAB situation ends. The end may be due to couple reunification in Europe (the event of interest in our analyses), breaking off (separation, divorce, widowhood), migration of one of the partners out of the countries under study (for instance out of Ghana for Ghanaian left behind women or out

\footnotetext{
${ }^{6}$ Numbers were too small to carry out analyses on couples where the female is the pionneer migrant. Priority was thus given to the constitution of homogeneous samples in order to facilitate results interpretation.

${ }^{7}$ In the case of Senegalese couples, the sample is made of 350 male migrants in Europe (France, Spain, Italy) and 193 left-behind females in Senegal. Congolese couples: 109 males respondents in Europe (Belgium and UK), 44 females in DRC. Ghanaian couples: 187 males respondents in Europe (Netherlands and UK) and 93 females in Ghana. Note that the information is (obviously) less detailed for partners than for the respondents themselves. Cases of asymetric information are detailed in .
}

\footnotetext{
${ }^{8}$ The year is the time unit level of data collection in the MAFE biographic questionnaire. International migration is thus defined as a stay of at least 12 months outside DR-Congo, Ghana or Senegal. This 12-month threshold also applies to couple's separation and reunification: a separation or a reunion lasting less than 12 month is not considered in our analyses.
} 
of the Netherlands or the UK for males migrants in Europe), or time of the survey, in which cases observations are censored.

\section{Data Analysis}

Using the MAFE data, event-history analysis is utilized to test the above mentioned hypotheses. Kaplan-Meier estimates are firstly used to study the timing of couple reunification among LATAB couples, in a double comparative way (across origin countries and, then, by destination for each Sub-Saharan flow separately). Secondly, for each of the African groups, a discrete-time logit event history model is used to estimate the probability of reunifying in Europe (Allison 1982). The clock of the model is the duration of the LATAB period; it is reset to zero each time an individual starts a new period of transnational partnership. Clustering at the individual level has been introduced in the models to take into account the fact that a same migrant can have multiple spells that are not independent. All results presented are weighted to account for the different sampling probabilities in each of the countries in which the survey took place. Details on the sampling and weighting strategies can be found in Schoumaker and Mezger (2013). Independent variables, most of which are time-varying and observed at $(\mathrm{t}-1)$, are presented in details in 
Table 3. They are classified in three categories:

(1) Partners' socio-economic characteristics. In the absence of more precise variables, the male socio-economic status is introduced in the models as a proxy for the official socioeconomic selection criteria for reunification (housing and income requirements). It certainly reflects state-selection, but it also reflects some sort of self-selection, since it is admitted that the lesser endowed migrants are more reluctant to reunify (Coe 2011). On the contrary, the education level of the left-behind women only pertains to self-selection since it is not related to official criteria of legal reunification in our period of observation (language tests for left behind reunification applicants were introduced after the time of the survey and only in France). More specifically, this variable is taken as a proxy for the females bargaining power within their couple and extended family.

(2) Couple situation and history. The variable "duration since LATAB" refers to the duration since the couples were separated because of migration. In some couples, partners never lived together because they started their relationship while they were already living in different countries. These unions are neither rare (13\% of our Congolese sample and about $50 \%$ of the Senegalese sample), nor a new phenomenon (Kraler, Kofman et al. 2011). The meaning of this variable depends on the context. It can either reflect the persistent control of the extended family over the migrants' matrimonial life (and/or the strong attachment of some migrants to their home social networks, as is the case in Senegal) and would thus rather prevent reunification in the contexts under study. Or, where women have more freedom to choose their partner (as in Congo), it can reflect a migration strategy, whereby women marry migrants with the intention to join them in Europe. In this case, unions that started at a distance would be expected to be associated with a quick reunification process, as previously observed by Lututala (2009). Two additional variables refer to the matrimonial status. One 
indicates whether the couple is married, the other whether the couple is polygamous. Both variables potentially indicate state-selection effects since all countries forbid reunification of polygamous families (or more precisely allow reunification with only one wife) and since marriage is a legal requirement in almost all European countries (where this is not required, the bureaucratic difficulties to prove that the partnership is stable enough are discouraging). Finally, the number of children is also introduced in the model. It is rather expected to delay reunification because it augments its costs (either economic costs if children are to move with the mother, or psychological costs if the children are to be left behind).

(3) Conditions of migration and stay in Europe. Each year, the "visit" variable indicates whether the migrant returned in his home country for less than a year during the three preceding years. Short stays in Congo, Ghana or Senegal are expected to delay reunification, as they are a way of "oiling" the functioning of families living across borders (Grillo and Mazzucato 2008). In a way, this variable is an indicator of a transnational way of life and reflects some sort of self-selection. Also time-varying, the legal status variable is a basic official criterion for reunification: it gives an account of state-selection. The last variable refers to the context at destination: it crosses the period (before ${ }^{9}$ and after 2003) and the destination country (for instance, Belgium vs. the UK for Congolese couples). This variable captures in a rough manner a wide range of economic, social, cultural or policy elements that may influence family reunification, including specific policies in this domain. The cut-off point, 2003, was not only chosen for its symbolic dimension (this is the year of the EU Directive on family reunion), but also because it is quite close to 2007 , the year for which we

\footnotetext{
${ }^{9}$ Observation starts in 1959 for Congolese couples, and 1961 for Ghanaian and Senegalese couples.
} 
dispose of a comparative index to measure the restrictiveness of family reunion policies in the various European countries of interest in our study (MIPEX, see Table 2). 
Table 3 about here)

\section{Results}

The first important result is -as expected- that couple reunification in Europe is not a very common outcome. On the contrary, living apart together across borders appears as a long lasting couple arrangement: after 10 years of geographical separation -a quite significant period in a couple's life-, the large majority of the couples have still a transnational way of life (Figure 1). At this point, $63 \%$ of the Congolese migrants in Europe have still their partner left behind in their home country, as $75 \%$ of the Ghanaian migrants and $81 \%$ of the Senegalese ones. Reversely, it means that the probability to reunify after 10 years oscillates between one couple out of three or four, depending on the origin. As expected (hypothesis 1), couples originating from the less gender egalitarian context, i.e. Senegal, are those with the lesser propensity to regroup. Those from DR Congo are, on the contrary, the more likely to reunify in Europe, as a probable result of a higher autonomy of females in this country and also of the political context that prevented migrants to return and prompted them to bring their family under safer skies. In any case, countries where living apart together within the borders is frequent, i.e. Senegal and Ghana (Figure 1), are also those with the higher rates of living apart together couples across borders.

The propensity to reunify in Europe is not only dependent on the migrants' origin. It also depends on the destination place, with sometimes deep gaps such as between Belgium and the UK in the case of Congolese couples (Figure 1). If policy expectations were fulfilled, we should observe that the more restrictive countries in terms of reunion policies are those with lesser levels of reunification. This is not at all what is observed. On the contrary: Congolese 
and Senegalese tend to regroup more quickly and more often in restrictive destinations (respectively the UK and France). How come? This result simply indicates that reunification policies are not the only determinant of couple reunion. For instance, the higher propensity of Congolese migrants to regroup in the UK is associated to their specific profile: refugees are much more frequent than in Belgium (Schoumaker and Flahaux 2013) and they form a population that both tends to have lesser intentions to return and a higher legal capacity to regroup (reunification being easier for refugees than for other migrants). A substitution effect is thus at play: migrants can regroup through another legal channel than reunification. Another mechanism explains that reunification for Senegalese migrants is less likely in Spain or Italy, precisely where policies are more open than in France. Actually, this openness applies to family migration as well as to labor migration, while France stopped to import foreign workers in the mid-1970s. Before the French government stopped labor migration, Senegalese migrants -as well as migrants from other regions- were engaged in circulatory movements. Then reunification in Europe was not a common practice; it rather occurred at origin, when the migrants returned. Reunification in France started to develop only some years after the government closed the borders to workers (Barou 1993). The difference between France and its Mediterranean neighbors on Figure 1 probably comes from the fact that labor migration remains an option in Italy and Spain and that Senegalese migrants still have the possibility to come and go in Spain and Italy, where they are labelled as "transmigrants" (Riccio 2001). The Senegalese case is thus exemplary of another substitution effect, where more restrictions in labor migration lead to more family reunification. The fact that reunification is less frequent in Spain and Italy could also reflect the fact that irregular migrants are more numerous there, which tends to deter reunification, as will be shown later.

(Figure 1 about here) 
The models results converge with the descriptive ones and confirm our third hypothesis. Controlling for a large set of individual and couple characteristics, they show -contrary to policy expectations- that couple reunification is not less likely in restrictive contexts. In the post-2003 period, the odds of reunion are higher, albeit non-significant, among of Congolese migrants in the restrictive UK than among their counterparts living in the more liberal Belgium (Table 5). Similarly, Senegalese migrants in the severe France have higher odds of reunification than Senegalese migrants in the more open Mediterranean countries (with a significant difference only between France and Italy).

\section{(Table 4 and Table 5 about here)}

That more restrictive contexts regarding reunification rules are not associated with lesser reunion in fact does not mean, off course, that there is no state selection in the process of couple reunification. This appears in the models results regarding several individual and couple characteristics. As expected, couples who are in principle not eligible for official reunification are indeed less likely to regroup. This is patent for polygamous couples as well as for the unmarried ones who have also significantly lower odds of reunification (Table 4). It remains however that a minority of reunified couples are not married at the time of reunification (from $4 \%$ among Senegalese to $13 \%$ among Congolese couples, Table 6). Similarly, migrants who do not hold a residence permit have significant lower odds of reunification than those who are documented (Table 4), which is not in contradiction with the fact that some undocumented migrants reunify on the "fringes of the law" (Gonzalez Ferrer 2011). This form of irregular de facto reunification culminates at $15 \%$ for Congolese couples; It is a much higher rate than for Senegalese or Ghanaians (respectively $2 \%$ and $4 \%$, Table 6), probably both because a lot of Congolese migrants entered Europe as asylum seekers without obtaining the status of refugee and because left behinds are prompter to leave a country in a severe political and economic crisis. 
(Table 6 about here)

Self-selection in the process of reunification is also patent in the results regarding the left behinds' education level. The higher it is, the more likely are the women to join their partner in Europe. As expected (hypothesis 2), this selection effect varies according to the social context at origin: it is higher where women enjoy less egalitarian conditions, as it can be observed when comparing Senegal with Ghana or Congo. The fact that selection by education is weakly significant in this later country may result not only from a better position of women in the society, but also certainly from the crisis situation (refugees are less selected than other types of migrants). The influence of the social context at origin is also reflected in the effect variations of the visit variable. In all groups, chances of reunion are diminished when migrants visit their home country, as short stays at home help to do family at a distance. However, the result is strongly significant only in Senegal, which echoes the fact that the social structures in this country strongly support a transnational way of life, with hometown and religious associations constantly reminding to the migrants their duties toward their home community, in addition of extended family demands (Barou 1993; Riccio 2001).

\section{Conclusion}

The objective of this paper was to study the timing and factors of reunification in Europe among sub-Saharan couples. We assembled pieces of evidence that reunification is the product of both a state and self-selection process, the "self" level referring to the couple, which is under influence of the family and social context at origin and wherein partners may have diverging aspirations. Pieces of this framework would need to be further researched to overcome the limitations of the analysis. It was not possible, for instance, with our data to search to what extent states and couples converge in their respective selection process. There 
are however some reasons to believe that they tend to similarly select the more integrated migrants at destination and the more adaptable left-behind partners at origin. This appears in the selection of the more educated left-behind women (who are not explicitly selected by the states). And it is likely - even though it remains to be shown- that the migrants who are undocumented or who have low incomes prefer to delay reunification, to avoid its costs and to protect their partners from their vulnerability. Another limitation of this work relates to the couple functioning. Albeit recognizing that the couple is not a unitary decision unit, we were not able to analyze the potential bargain at play within the couple regarding reunification.

Even though it does not cover the whole Africa, the diversity of the groups under study allows, to some extent, to generalize the findings. A first important result is that reunification is not as common as usually perceived in the public debate. Actually, living apart together across borders is much more frequent than reunion, even during quite long periods. To what extent is this specific to Sub-Saharan Africa? In Europe, studies on family migration have shown that African migrants take more time to reunify than other groups (Esteve and Cortina 2009; González-Ferrer, Baizán et al. 2012). However, the high frequency of non-reunification was coined by Kanaiaupuni (2000) in the case of Mexican migration. She insisted on the role of gender relationships to explain this situation. Working on female migration in a set of four Latin American countries, Massey et al. (2006) pointed the correlation between the degree of patriarchality and the level and factors of migration among women. Our results on African migration to Europe confirm this relationship. Where the origin society is less gender egalitarian, reunification is less frequent and more selective. In contexts where women face harsh discrimination and where they undergo a vivid social control, the more educated ones are much more likely to join their partner in Europe. The incentives to migrate and the costs of migration are lesser for the left behinds who live in more egalitarian contexts. Beyond gender relationships, the degree of social control by the elders and through social structures, 
such as hometown or religious associations, is also a determinant to explain variations in reunification levels. Where they are high (such as in Senegal), women are expected to remain behind in order to ensure that the migrant will keep in mind his obligations towards his community.

Reunification is not only a matter of social control at origin. Immigration policies are also believed -at least by governments- to determine the levels of reunification. Our results starkly contrast with the policy expectation that more restrictiveness would lead to less reunification. In the cases of Senegalese and Congolese migration, we were able to compare destination countries that are "slightly favorable" (Belgium, Spain, Italy) to reunification with "halfway favorable" countries (France, UK), according to the MIPEX classification. We showed an apparent paradox: for both groups, reunification is more likely in more restrictive countries. The basic lesson to learn from this result is that family reunion policies are not sufficient to actually shape reunification behaviors. Many other factors are at play and migrants and their families detain some agency on their mobility arrangements. Legal reunification is just one channel of entry into Europe and other channels can be used by couples who aspire to reunify, including through irregular paths. Such substitution effects can undermine the effectiveness of restrictive measures in family migration policies (Czaika and De Haas 2013). On the other hand, severe policies in labor migration can lead to more reunification even where reunion procedures are rather restrictive, as observed in the case of Senegalese migration in France vs. Spain and Italy. Even though they set the rules and decide which migrants can officially reunify or not, states at destination are definitely not the only players in the process of selection into reunification in Europe. 


\section{References}

Allison, P. (1982). Discrete time methods for the analysis of event histories. Sociological Methodology. S. Leinhardt. San Francisco, Jossey-Bass: 61-98.

Baizán, P., C. Beauchemin and A. González-Ferrer (2014). "An Origin and Destination Perspective on Family Reunification: The Case of Senegalese Couples." European Journal of Population 30(1): 65-87.

Barou, J. (1993). "Les immigrations africains en France : des "navigateurs" au regroupement familial." Revue Française des Affaires Sociales(1).

Bauböck, R. and T. Faist (2010). Diaspora and Transnationalism: Concepts, Theories and Methods. Amsterdam, Amsterdam University Press.

Beauchemin, C. (2012). Migrations between Africa and Europe: Rationale for a Survey Design. MAFE Methodological Note 5. Paris, Ined: 45.

Bledsoe, C. and P. Sow (2008). "Family Reunification Ideals and the Practice of Transnational Reproductive Life among Africans in Europe." MPIDR WORKING PAPER WP (2008-001): 18.

Bryceson, D. F., U. Vuorela and ebrary Inc. (2002). The transnational family new European frontiers and global networks. Cross-cultural perspectives on women,. Oxford ; New York, Berg,: xi, 276 p.

Carling, J., C. Menjivar and L. Schmalzbauer (2012). "Central themes in the study of transnational parenthood." Journal of Ethnic and Migration Studies 38(1). 
Coe, C. (2011). "What is the impact of transnational migration on family life? Women's comparisons of internal and international migration in a small town in Ghana." American Ethnologist 38(1): 148-1643.

Czaika, M. and H. De Haas (2013). "The Effectiveness of Immigration Policies." Population and Development Review 39(3): 487-508.

De Haas, H. and C. M. Fokkema (2010). "Intra-household conflicts in migration decisionmaking: return and pendulum migration in Morocco." Population and Development Review 36(3): 541-561.

Esteve, A. and C. Cortina (2009). Trajectories to family formation of international migrants. XXVI International Population Conference. IUSSP. Marrakech.

Findley, S. (1997). Migration and Family Interactions in Africa. Family, Population and Development. A. Adepoju. London, Zed Books: 109-138.

González-Ferrer, A. (2007). "The reunification of partners and children by male labor immigrants in Germany." special issue of Zeitschrift für Familienforschung on the topic Immigrant Families in Europe 3: 10-33.

González-Ferrer, A., P. Baizán and C. Beauchemin (2012). "Child-Parent Separations among Senegalese Migrants to Europe: Migration Strategies or Cultural Arrangements?" The Annals of the American Academy of Political and Social Science 643(1): 106 - 133.

Gonzalez Ferrer, A. (2011). Spousal Reunification among Recent Immigrants in Spain: Links with Undocumented Migration and the Labour Market. Gender, Generations and the Family in International Migration. A. Kraler, E. Kofman, M. Kohli and C. Schmoll. Amsterdam, Amsterdam University Press: 193-218. 
Grillo, R. and V. Mazzucato (2008). "Africa <> Europe: A Double Engagement." Journal of Ethnic and Migration Studies 34(2): 175-198.

Guilmoto, C. (1998). "Institutions and Migrations. Short Term versus Long Term Moves in Rural West Africa." Population Studies 52: 85-103.

Hondagneu-Sotelo, P. (1992). "Overcoming Patriarchal Constraints: The Reconstruction of Gender Relations Among Mexican Immigrant Women and Men " Gender \& Society September 6: 393-415.

Huddleston, T. (2011). "Right to Family Reunion: The Dynamics between EU Law and National Policy Change " Migration Policy Group Briefings for Green Paper on Family Reunion 2: 9.

Kanaiaupuni, S. M. (2000). "Reframing the Migration Question: an Analysis of Men, Women, and Gender in Mexico." Social Forces 78(4): 1311-1347.

Kofman, E. (2000). "The invisibility of skilled female migrants and gender relations in studies of skilled migration in Europe." International Journal of Population Geography 6: 45-59.

Kraler, A. (2010). Civic Stratification, Gender and Family Migration Policies in Europe. Final Report. Vienna, International Centre for Migration Policy Development (ICMPD).

Kraler, A., E. Kofman, M. Kohli and C. Schmoll (2011). Gender, Generations and the Family in International Migration. Amsterdam, Amsterdam University Press.

Le Gall, J. (2005). "Familles transnationales : bilan des recherches et nouvelles perspectives." Les Cahiers du Gres 5(1): 29-42. 
Lututala, M. (2009). Immigrer en France : le combat des femmes congolaises. Du genre et de l'Afrique : hommage à Thérèse Locoh. Paris, Institut national d'études démographiques 425436.

Mazzella, S. and H. Boubakri (2011). "L'horizon transnational d'une famille tunisienne élargie." Autrepart 1-2(57-58): 111-126.

Mazzucato, V. (2009). "Informal Insurance Arrangements in Ghanaian Migrants' Transnational Networks: The Role of Reverse Remittances and Geographic Proximity." World Development 37(6): 1105-1115.

Mazzucato, V. and D. Schans (2011). "Transnational Families and the Well-Being of Children: Conceptual and Methodological Challenges." Journal of Marriage and Family 73(4): 704-712.

Mezger, C. and A. Gonzalez-Ferrer (2013). The ImPol Data-base: A New Tool to Measure Immigration Policies in France, Italy and Spain since the 1960s. MAFE Working Paper. Paris, INED: 43.

Mondain, N. (2009). Assessing the effects of out-migration on those left behind in Senegal: local family dynamics between change and continuity. XXVI International Population Conference. IUSSP. Marrakech.

Parrado, E. A. and C. A. Flippen (2005). "Migration and Gender among Mexican Women." American Sociological Review 70(4): 606-632.

Pascouau, Y. and H. Labeyle (2011). Conditions for family reunification under strain - A comparative study in nine EU member states, King Baudouin Foundation / European Policy Centre. 
Pilon, M. and K. Vignikin (2006). Ménages et familles en Afrique subsaharienne. Paris, Éditions des archives contemporaines.

Razy, E. and V. Baby-Collin (2011). "La famille transnationale dans tous ses états." Autrepart 57-58: 7-22.

Riccio, B. (2001). "From "Ethnic Group" to "Transnational Community"? Senegalese Migrants' Ambivalent Experiences and Multiple Trajectories." Journal of Ethnic and Migration Studies 27(4): 583-599.

Riccio, B. (2008). "West African Transnationalisms Compared: Ghanaians and Senegalese in Italy." Journal of Ethnic and Migration Studies 34(2): 217-234.

Schoonvaere, Q. (2010). Etude de la migration congolaise et de son impact sur la présence congolaise en Belgique. Analyse des principales données démographiques. . Bruxelles, Centre pour l'égalité des chances et la lutte contre le racisme.

Schoumaker, B. and M.-L. Flahaux (2013). Changing Patterns Of Congolese Migration. MAFE Working Paper. Paris, INED: 43.

Schoumaker, B., C. Mezger, N. Razafindratsima and A. Bringé (2013). Sampling and Computation Weights in the MAFE Surveys. MAFE Methodological Note 6: 73.

Tall, S. M. and A. Tandian (2010). Entre regroupement familial et migrations autonomes des femmes sénégalaises. Quelle analyse de genre des migrations sénégalaises ? Note d'analyse et de synthèse - Série sur genre et migration - Module socio-politique, Florence, CARIM.

Toma, S. and S. Vause (2013). "On Their Own? A Study of Independent Versus Partnerrelated Migration from the Democratic Republic of Congo and Senegal." Journal of Intercultural Studies 34(5): 533-552. 
Table 1. Contextual Information on Regions of Origin - Gender Relationships Indicators (

\begin{tabular}{|l|c|c|c|}
\hline & DR Congo & Ghana & Senegal \\
\hline Family indicators & & & $0.1 \%$ \\
\hline Proportion of females (25-49) in consensual union & $8.7 \%$ & $10.1 \%$ & $5.0 \%$ \\
\hline Proportion of divorced females (25-49) & $6.3 \%$ & $10.7 \%$ & $21.7 \%$ \\
\hline $\begin{array}{l}\text { Proportion of household heads in partnership who are not } \\
\text { living with (any of) their partner }\end{array}$ & $9.8 \%$ & $41.0 \%$ & $19.6 \%$ \\
\hline Proportion of all married men in polygamous union & $5.1 \%$ & $2.1 \%$ & $39.8 \%$ \\
\hline Socio-economic indicators & & & $13.7 \%$ \\
\hline Proportion of women among students in tertiary education & $45.1 \%$ & $52.8 \%$ & $3 \%$ \\
\hline $\begin{array}{l}\text { Proportion of women (25+) who have attained post- } \\
\text { secondary education }\end{array}$ & $16.1 \%$ & $13.7 \%$ & $33.6 \%$ \\
\hline Proportion of working age women (15+) that are employed & $41.1 \%$ & $55.5 \%$ & 2 \\
\hline Source: MAFE-Congo (2009-2010), MAFE-Ghana (2009-2010), MAFE-Senegal (2008)- Household surveys. Weighted results. \\
\hline
\end{tabular}

Table 2. Family Reunification Policies in Europe: Measurement of Restrictiveness in 2007 (MIIPEX).

\begin{tabular}{|l|c|c|c|c|c|c|}
\hline & Belgium & UK & $\begin{array}{c}\text { The Nether- } \\
\text { lands }\end{array}$ & France & Spain & Italy \\
\hline Global index & 70 & 56 & 59 & 53 & 76 & 78 \\
\hline Eligibility & 65 & 56 & 45 & 35 & 80 & 65 \\
\hline $\begin{array}{l}\text { Conditions of acquisition } \\
\text { of status }\end{array}$ & 67 & 58 & 42 & 39 & 67 & 67 \\
\hline Security of status & 75 & 75 & 50 & 63 & 100 & 88 \\
\hline $\begin{array}{l}\text { Rights associated with } \\
\text { status }\end{array}$ & 67 & 42 & 100 & 75 & 58 & 92 \\
\hline
\end{tabular}

Source: Mipex indexes on family reunification in 2007, MIPEX (Migrant Integration Policy Index), http://www.mipex.eu/

NB: The higher the index, the more permissive the rules regarding family reunification. 
Table 3. Variables used in the models. Sample description (Observations at time of censoring or reunification in Europe, weighted percentages)

\begin{tabular}{|c|c|c|c|c|c|}
\hline Variables & Categories & $\begin{array}{c}\text { Senegalese } \\
\text { couples }\end{array}$ & $\begin{array}{c}\text { Ghanaian } \\
\text { couples }\end{array}$ & $\begin{array}{c}\text { Congolese } \\
\text { couples }\end{array}$ & Variable Description \\
\hline \multicolumn{6}{|c|}{ Socio-demographic characteristics } \\
\hline \multirow{2}{*}{ Gender } & Male & 71.9 & 62.6 & 43.3 & \multirow{2}{*}{ Time constant } \\
\hline & Female & 28.1 & 37.4 & 56.7 & \\
\hline \multirow{3}{*}{$\begin{array}{l}\text { Migrant's socio- } \\
\text { economic status } \\
\text { (Male at } \\
\text { destination) }\end{array}$} & $\begin{array}{l}\text { No skilled and self } \\
\text { employed }\end{array}$ & 57.5 & 37.6 & 8.4 & \multirow{3}{*}{$\begin{array}{l}\text { Time constant. } \\
\text { Asymmetric information: Time of the survey for the } \\
\text { interviewee. For spouse, situation considered at the moment of } \\
\text { entry in union. }\end{array}$} \\
\hline & $\begin{array}{l}\text { Skilled and } \\
\text { Professionals }\end{array}$ & 31.3 & 45.7 & 46.6 & \\
\hline & $\begin{array}{l}\text { Not employed } \\
\text { (incl. students) }\end{array}$ & 11.2 & 16.7 & 45 & \\
\hline \multirow{3}{*}{$\begin{array}{l}\text { Partner's level of } \\
\text { education } \\
\text { (Female at origin) }\end{array}$} & None and primary & 63.7 & 4.8 & 4.4 & \multirow{3}{*}{$\begin{array}{l}\text { Time constant. } \\
\text { Asymmetric information: Time of the survey for the } \\
\text { interviewee. For spouse, education level considered at the } \\
\text { moment of entry in union. }\end{array}$} \\
\hline & Secondary & 32.3 & 48.6 & 47.6 & \\
\hline & Tertiary & 4.00 & 46.6 & 48 & \\
\hline \multicolumn{6}{|l|}{ Couple situation } \\
\hline \multirow[b]{2}{*}{$\begin{array}{l}\text { Years lived in } \\
\text { LATAB (Living } \\
\text { Apart Together } \\
\text { Across Borders) }\end{array}$} & $<=3$ years & 41.9 & 72.2 & 79.9 & \multirow[b]{2}{*}{$\begin{array}{l}\text { Time-varying in the models (observed at } \mathrm{t}-1 \text { ). Duration since the } \\
\text { partners started to live in separate countries. }\end{array}$} \\
\hline & $>3$ years & 58.1 & 27.8 & 20.1 & \\
\hline \multirow{2}{*}{ Married } & no & 13.7 & 38.9 & 46.4 & \multirow{2}{*}{ Time varying (observed at $\mathrm{t}-1$ ). } \\
\hline & yes & 86.3 & 61.1 & 53.6 & \\
\hline \multirow{2}{*}{$\begin{array}{l}\text { Union started at a } \\
\text { distance }\end{array}$} & no & 81.0 & 89.2 & 95.5 & \multirow{2}{*}{ Time varying (observed at $\mathrm{t}-1$ ). } \\
\hline & yes & 19.0 & 10.8 & 4.4 & \\
\hline \multirow[b]{2}{*}{ Polygamous } & no & 80.3 & 61 & 93.9 & \multirow{2}{*}{$\begin{array}{l}\text { Time varying in the models (observed at t-1). } \\
\text { Asymmetric information: Among male respondents, polygamy } \\
\text { is deduced from the partnerships' history. Among female } \\
\text { respondents, the information was collected only in MAFE } \\
\text { Senegal: for each union, they were asked whether they have/had } \\
\text { co-spouse(s). }\end{array}$} \\
\hline & yes & 19.7 & 39 & 6.1 & \\
\hline \multicolumn{6}{|c|}{ Conditions of migration } \\
\hline \multirow{3}{*}{$\begin{array}{l}\text { Legal status of the } \\
\text { migrant in Europe }\end{array}$} & No & 12.3 & 4.3 & 6.7 & \multirow{3}{*}{$\begin{array}{l}\text { Time varying in the models (observed at t-1). } \\
\text { Each year, indicates the migrant's legal status. } \\
\text { Asymetric information: legal status was collected only about } \\
\text { respondents themselves, i.e. migrants in Europe (including those } \\
\text { who returned to Africa). The information is missing when the } \\
\text { respondent was the partner left behind in Africa. Missing status } \\
\text { is coded as a category in order to keep all observations in the } \\
\text { data set. }\end{array}$} \\
\hline & yes & 71.7 & 62.6 & 50.2 & \\
\hline & missing & 16 & 33.1 & 43.1 & \\
\hline \multirow{2}{*}{$\begin{array}{l}\text { Ever visited } \\
\text { partner }\end{array}$} & no & 49.9 & 75.1 & 92.6 & \multirow{2}{*}{$\begin{array}{l}\text { Time varying (observed at } t-1 \text { ). Each year, indicates whether the } \\
\text { migrant returned for at least one short stay (less than a year) in } \\
\text { his home country during the } 3 \text { preceding years ( } t-3, t-2 \text { and } t-1 \text { ). }\end{array}$} \\
\hline & yes & 50.1 & 24.9 & 7.4 & \\
\hline \multirow{6}{*}{ Period*Destination } & Before 2003 & France: 27.5 & UK: 62.1 & $\begin{array}{l}\text { Belgium: } \\
28.6\end{array}$ & \multirow{6}{*}{ Time varying in the models (observed at $\mathrm{t}-1$ ). } \\
\hline & After 2003 & France: 6.1 & UK: 30.7 & Belgium: 34 & \\
\hline & Before 2003 & Italy: 26.7 & $\begin{array}{l}\text { The } \\
\text { Netherlands: } \\
5.7\end{array}$ & UK: 22.9 & \\
\hline & After 2003 & Italy: 18.7 & $\begin{array}{l}\text { The } \\
\text { Netherlands: } \\
1.5\end{array}$ & UK: 14.5 & \\
\hline & Before 2003 & Spain: 8.5 & - & - & \\
\hline & After 2003 & Spain: 12.4 & - & - & \\
\hline
\end{tabular}


Table 4. Models Results

\begin{tabular}{|c|c|c|c|c|c|c|c|}
\hline \multirow[b]{2}{*}{ Variables } & \multirow[b]{2}{*}{ Categories } & \multicolumn{2}{|c|}{ Congolese couples } & \multicolumn{2}{|c|}{ Ghanaian couples } & \multicolumn{2}{|c|}{ Senegalese couples } \\
\hline & & Gross effects $^{\circ}$ & Model 1 & Gross effects $^{\circ}$ & Model 2 & Gross effects $^{\circ}$ & Model 3 \\
\hline \multicolumn{8}{|c|}{ Partners' socio-economic characteristics } \\
\hline \multirow{3}{*}{$\begin{array}{l}\text { Female's level of } \\
\text { education (Left } \\
\text { behind at origin) }\end{array}$} & Primary and less & 1.00 & 1.00 & \multirow{2}{*}{1.00} & \multirow{2}{*}{1.00} & 1.00 & 1.00 \\
\hline & Secondary & $0.41^{*}$ & 0.78 & & & $2.30^{* * *}$ & $4.45^{* * * *}$ \\
\hline & Tertiary education & $0.25 * *$ & 1.16 & $2.50^{*}$ & $4.06^{*}$ & $4.32 * * *$ & $7.89^{* * *}$ \\
\hline \multirow{3}{*}{$\begin{array}{l}\text { Male's socio- } \\
\text { economic status } \\
\text { (Migrant at } \\
\text { destination) }\end{array}$} & \begin{tabular}{|l}
$\begin{array}{l}\text { Not } \\
\text { employed/Student }\end{array}$ \\
\end{tabular} & 1.00 & 1.00 & 1.00 & 1.00 & 1.00 & 1.00 \\
\hline & \begin{tabular}{|l|}
$\begin{array}{l}\text { Unskilled or self } \\
\text { employed }\end{array}$ \\
\end{tabular} & $2.50^{*}$ & 1.19 & 1.95 & $1.88+$ & 0.88 & 1.83 \\
\hline & $\begin{array}{|ll|}\text { Skilled } & \text { and } \\
\text { Professionals } & \\
\end{array}$ & $2.40+$ & $3.07 *$ & 1.15 & $2.73^{* * *}$ & $1.75^{+}$ & $2.53^{*}$ \\
\hline \multicolumn{8}{|c|}{ Couple's characteristics } \\
\hline \multirow{2}{*}{$\begin{array}{l}\text { Duration since } \\
\text { LATAB }\end{array}$} & $<=3$ years & 1.00 & 1.00 & 1.00 & 1.00 & 1.00 & 1.00 \\
\hline & $>3$ years & $0.16^{* * *}$ & $0.12 * * *$ & $0.19 * * *$ & $0.11^{* * *}$ & $0.15^{* * *}$ & $0.27 * * *$ \\
\hline \multicolumn{2}{|c|}{ Union started at a distance (ref: no) } & $3.16^{* * *}$ & $4.61 * *$ & 1.13 & 1.43 & 1.02 & 0.88 \\
\hline \multicolumn{2}{|l|}{ Married (ref : no) } & $3.73 *$ & 1.26 & $7.19^{* * *}$ & $7.96^{* * *}$ & $3.11 * *$ & $4.06^{* * *}$ \\
\hline \multicolumn{2}{|c|}{ Polygamous couple (ref: no) } & 1.34 & 0.48 & 1.35 & $0.16^{* * *}$ & $0.38 * * *$ & $0.38 * * *$ \\
\hline \multicolumn{2}{|l|}{ Children (number) } & $1.14^{+}$ & 0.99 & $0.85+$ & $0.73^{* * *}$ & 0.96 & 0.97 \\
\hline \multicolumn{8}{|c|}{ Migration conditions } \\
\hline \multicolumn{2}{|c|}{ Visited partner (ref: no) } & 0.72 & $0.21^{+}$ & 1.30 & 0.85 & 0.95 & $0.41^{* * *}$ \\
\hline \multirow{3}{*}{ Stay permit } & No & 1.00 & 1.00 & 1.00 & 1.00 & 1.00 & 1.00 \\
\hline & Yes & 0.82 & $2.18+$ & $2.06^{+}$ & $1.69^{+}$ & $15.41^{* * *}$ & $10.95^{* * *}$ \\
\hline & Missing & $0.01 * * *$ & $0.01 * * *$ & $0.01 * * *$ & $0.01^{* * *}$ & 0.95 & $0.18^{*}$ \\
\hline \multicolumn{2}{|c|}{ Destination country $*$ Period } & \multicolumn{6}{|l|}{ See Table 5} \\
\hline \multicolumn{2}{|c|}{ Constant } & - & $0.03 * * *$ & $2-$ & $0.06^{* * *}$ & - & $0.01 * * *$ \\
\hline \multicolumn{2}{|l|}{ Sample sizes } & \multicolumn{2}{|c|}{$\begin{array}{c}\mathrm{n}=153 \text { couples } \\
\text { person-years }=636\end{array}$} & \multicolumn{2}{|c|}{$\begin{array}{c}\mathrm{n}=280 \text { couples } \\
\text { person-years }=1,224\end{array}$} & \multicolumn{2}{|c|}{$\begin{array}{c}\mathrm{n}=543 \text { couples } \\
\text { person-years }=4077\end{array}$} \\
\hline
\end{tabular}


Table 5. Models Results. Interaction Effects of the Period and the Destination countries (results of models 1 to 3 )

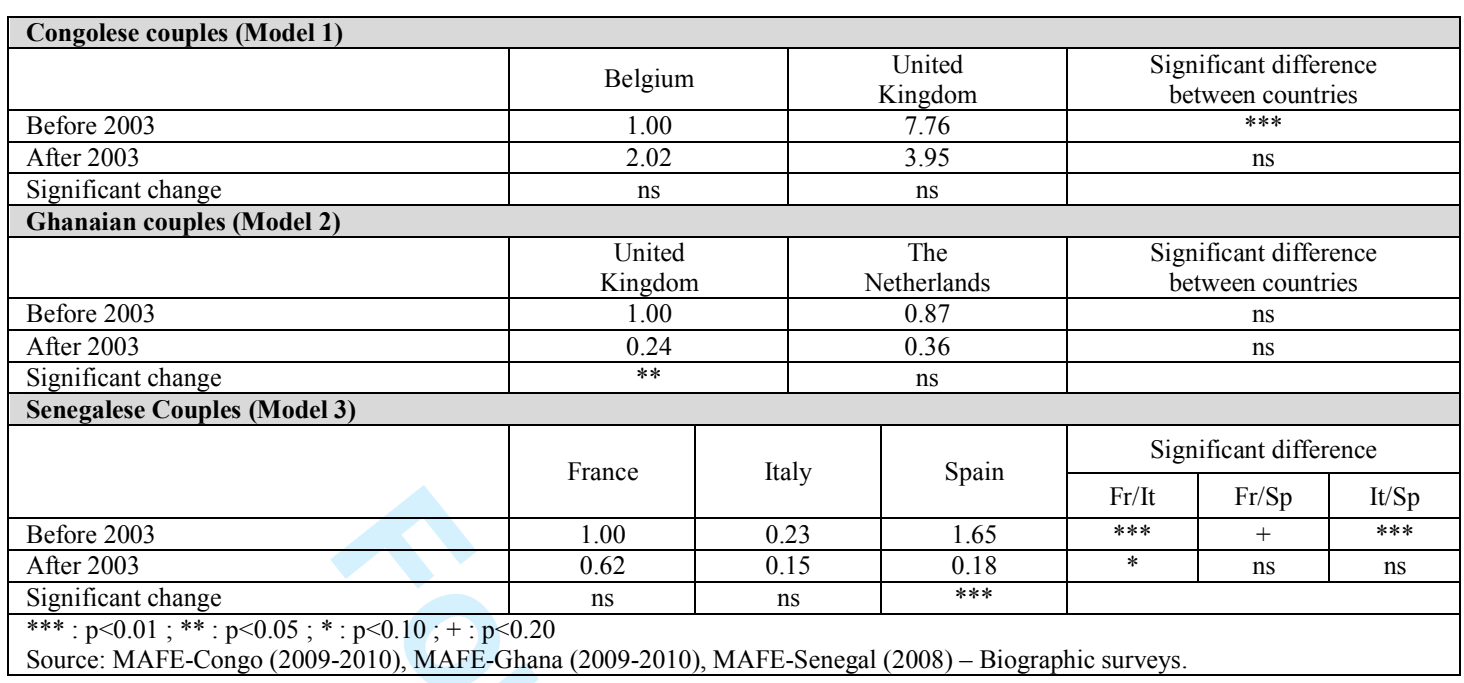

Table 6. Measures of de Facto Reunification (Weighted percentages at the time of Reunification in Europe among reunified couples)

\begin{tabular}{|l|c|c|c|}
\hline & $\begin{array}{c}\text { Congolese } \\
\text { couples }\end{array}$ & $\begin{array}{c}\text { Ghanaian } \\
\text { couples }\end{array}$ & $\begin{array}{c}\text { Senegalese } \\
\text { couples }\end{array}$ \\
\hline Matrimonial Status & & & \\
\hline Not married & 13 & 10 & 4 \\
\hline Married & 87 & 90 & 96 \\
\hline Migrant's legal status & & & \\
\hline No stay permit & 15 & 4 & 2 \\
\hline Stay permit & 84 & 95 & 96 \\
\hline Missing & 1 & 1 & 3 \\
\hline Total & 100 & 100 & 100 \\
\hline Number of reunified couples in Europe & 79 & 112 & 139 \\
\hline Source: MAFE-Congo (2009-2010), MAFE-Ghana (2009-2010), MAFE-Senegal (2008) - Biographic surveys. \\
\hline
\end{tabular}


Figure 1. Time to reunification in Europe for LATAB couples from DR-Congo, Ghana and Senegal
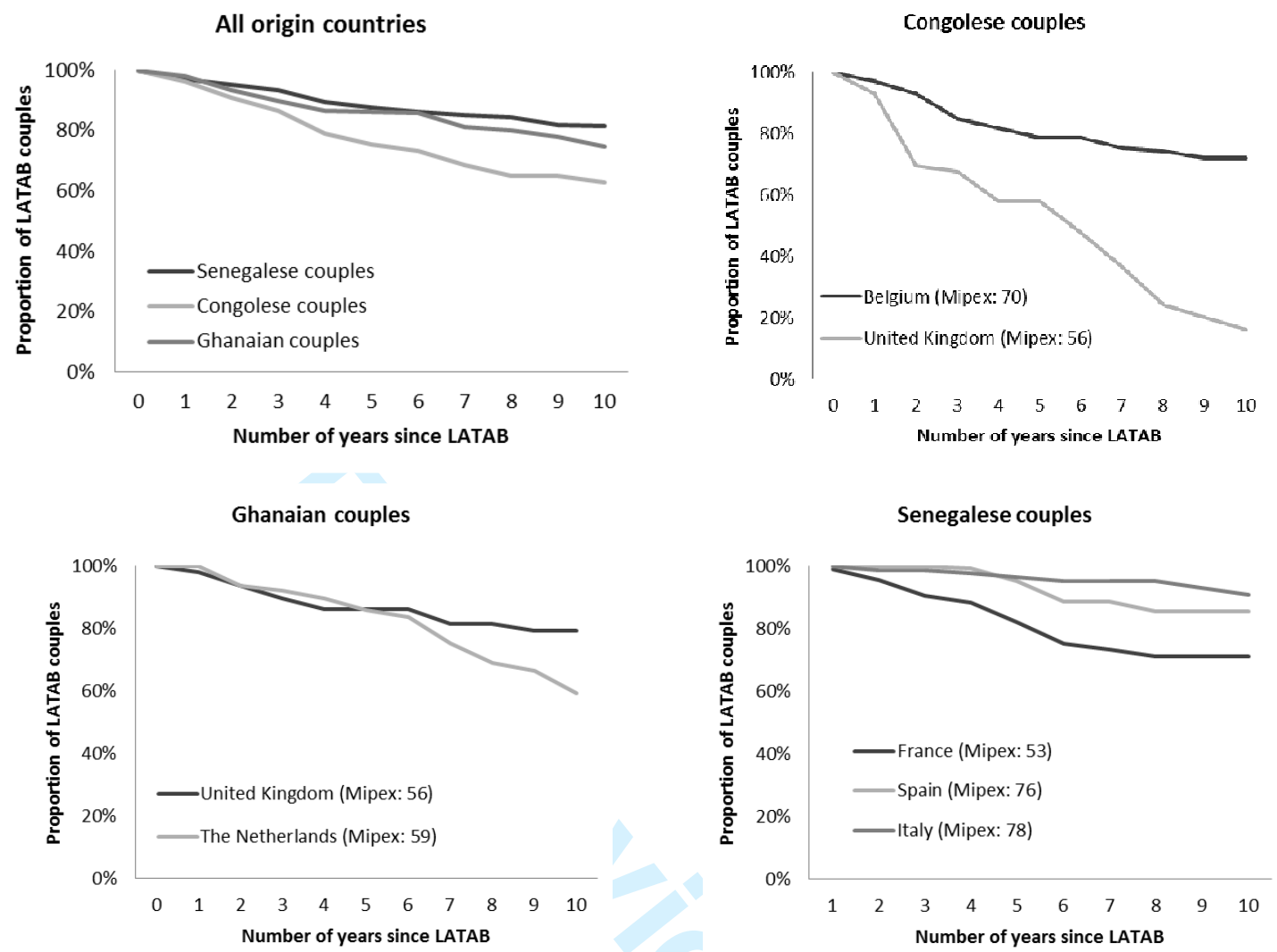

Source: MAFE-Congo (2009-2010), MAFE-Ghana (2009-2010), MAFE-Senegal (2008) - Biographic surveys ; MIPEX index on family reunification (2007), see details in Table 2. 